\title{
Macroeconomic effects of fiscal policy in the European Union, with particular reference to transition countries
}

RILIND KABASHI, Ph.D.*

Article**

JEL: E62, C33, H30

https://doi.org.10.3326/pse.41.1.7

\footnotetext{
* The views expressed in this paper are those of the author and do not necessarily represent the views of the National Bank of the Republic of Macedonia. The author is grateful to Geoff Pugh of Staffordshire University for helpful comments and to Georgios Georgiadis of the European Central Bank for the Matlab code for Panel VAR and additional advice provided in our correspondence. Also, the author is grateful to two anonymous referees for their comments.

** Received: October 19, 2016

Accepted: December 1, 2016
}

A previous version of this paper was presented at the conference Public Sector Economics organized by the Institute of Public Finance and Friedrich-Ebert-Stiftung in Zagreb on October 14-15, 2016.

Rilind KABASHI

Monetary Policy and Research Department, National Bank of the Republic of Macedonia, Blvd Kuzman Josifovski Pitu 1, 1000 Skopje, Republic of Macedonia

e-mail: kabashir@nbrm.mk

ORCID iD: 0000-0001-7597-6495 


\section{Abstract}

This study empirically investigates the short- to medium-term effects of fiscal policy on output and other macroeconomic variables in European Union countries between 1995 and 2012, with particular reference to transition countries. It applies Panel Vector Auto Regression with recursive identification of government spending shocks as the most appropriate method for the aim of the study and the sample used. The main results indicate that expansionary spending shocks have a positive, but a relatively low effect on output, with the fiscal multiplier around one in the year of the shock and the following year, and lower thereinafter. There are indications that this result is driven by the recent crisis, as multipliers are considerably lower in the pre-crisis period. Effects of fiscal policy are strongly dependent on country structural characteristics. Fiscal multipliers are higher in new European Union member states, in countries with low public debt and low trade openness. Further, spending shocks are followed by rising debt levels in old member states, which could be related well to the recent European debt crisis. Finally, the analysis of the transmission mechanism of fiscal policy yields results that are consistent with both extended Real Business Cycle models and extended New Keynesian models.

Keywords: fiscal policy, panel VAR, European Union, transition countries

\section{INTRODUCTION}

The aim of this paper is to analyse the effects of fiscal policy in European Union (EU) countries, with a particular focus on transition countries. The empirical investigation therefore focuses on four key questions of academic and policy importance: (i) what is the short- to medium-run effect of fiscal policy on output, i.e. what is the size and sign of fiscal multipliers? (ii) what are the short- to medium-run effects of fiscal policy on other key macroeconomic variables? (iii) how do main country structural characteristics affect the size and sign of fiscal multipliers? (iv) what is the transmission mechanism of fiscal policy, i.e. is it more closely related to neo-classical or to New Keynesian predictions?

In order to investigate these issues, this paper uses Panel Vector Auto Regression with recursive identification of government spending shocks, with annual data between 1995 and 2012. The main result of the study is that higher spending does result in higher GDP in the entire sample, but the size of the fiscal multiplier is around one, implying that the effects of fiscal policy are relatively limited. There are indications that this result is driven by the recent crisis, as multipliers are considerably lower in the pre-crisis period. The analysis of sub-samples according to country characteristics also yields some important insights. In particular, fiscal multipliers are higher in new European Union member states, in countries with low public debt and low trade openness. Further, spending shocks are followed by rising debt levels in old member states, which could well be related to the recent European debt crisis. Last but not least, the analysis of the transmission mechanism of fiscal policy suggests that spending shocks cause rises in both private 
investment and consumption, with the latter being supported by higher real wages and higher employment. This is in line with findings in most other empirical studies, and also consistent with predictions from extensions of both Real Business Cycle and New Keynesian models.

This paper builds upon and extends the extensive body of literature on the effects of fiscal policy in several important aspects. First, unlike the vast majority of studies, which focus on a single country (mostly the US) or a few developed countries, our study focuses on 27 EU member states as of 2012. Related to this, the study includes most European transition countries, which is an important extension bearing on mind the relative scarcity of empirical studies on the effects of fiscal policy in transition countries. In order to study fiscal policy in a group of countries, we use panel VAR, which combines the advantages of panel and VAR methods. Second, the study provides an extensive investigation of the possible influence of country structural characteristics on the effects of fiscal policy. Third, the study provides additional details on the transmission mechanism of fiscal policy. Finally, based on the results of the extensive investigation, the study provides recommendations that should be useful to policymakers when designing and implementing fiscal policy.

This study proceeds as follows. The relevant theoretical and empirical literature is briefly reviewed in the next section. Section 3 presents the methodology of investigation, data and model specification. Section 4 analyses the effects of fiscal policy in the overall sample and in several sub-samples. Section 5 modifies the baseline specification in order to investigate the transmission mechanism in more detail. The final section concludes and offers some policy recommendations.

\section{LITERATURE REVIEW}

The recent crisis and the zero bound for nominal interest rates highlighted the importance of fiscal policy in fighting the recession. This reignited the interest of the theoretical and empirical literature in the effects of fiscal policy on output (fiscal multipliers) and in other macroeconomic variables. Indeed, as Romer (2011) notes, between 2009 and 2011 there have been more studies on the effects of fiscal policy than in the previous quarter century. However, there is little consensus in the modern theoretical and empirical literature regarding the size of the fiscal multiplier and the transmission mechanism of fiscal policy shocks ${ }^{1}$. Theoretical studies relying on Real Business Cycle (RBC) models, such as Aiyagari, Christiano and Eichenbaum (1992) or Baxter and King (1993), tend to find that fiscal policy has modest effects on output, and that expansionary fiscal policy increases labour supply and lowers private consumption due to the dominance of wealth effects. Baseline New Keynesian models (e.g. Linnemann and Schabert, 2003) also tend to find that wealth effects dominate and that the multiplier is between

\footnotetext{
${ }^{1}$ A comprehensive review of the extensive theoretical and empirical literature is out of the scope of the current study. Therefore, we only briefly review the main contributions and then proceed with our empirical investigation. For reviews of the theoretical literature see Hebous (2011) and Hemming, Kell and Mahfouz (2002). For meta-regressions of the empirical literature see Rusnak (2011) and Gechert and Will (2012).
} 
zero and one, while expansionary spending shocks result in lower private consumption and higher labour supply.

Various studies have provided extensions of baseline RBC and New Keynesian theoretical models. In most cases, these extensions are aimed at addressing the puzzling finding of lower private consumption in the wake of spending shocks in theoretical models, as opposed to the higher private consumption, which is found in most empirical studies. RBC models are extended by Linnemann (2006) with non-separability in the utility of consumption and leisure and intertemporal consumption elasticity smaller than one, and also by Ravn, Schmitt-Grohe and Uribe (2006) with monopolistic competition and "deep habits" in the personal consumption of individual goods. Further, Galí, López-Salido and Vallés (2007) extend a standard New Keynesian model to allow the existence of Ricardian and nonRicardian households, with the latter behaving according to a rule of thumb and consuming all their disposable income each period, without borrowing or saving.

Leeper (2010) notes that the one clear message from the vast empirical and theoretical literature is that fiscal multipliers are "all over the map". Coenen et al. (2012) note that despite numerous advantages of structural economic models, the incomplete consensus on structural features and calibration can have an important effect on results on fiscal multipliers. Old Keynesian models, represented in the IS-LM framework, have fiscal multipliers larger than one. On the other hand, the baseline RBC model of Baxter and King (1993) yields a short-run output multiplier between $-2,5$ and below 1, depending on whether government shocks are temporary or permanent and whether they are financed by lump-sum or distortionary taxes. In their meta-regression analysis, Gechert and Will (2012) also note that the size of fiscal multipliers in neoclassical models is usually between zero and one. Extensions of the RBC framework also yield multipliers lower than one, which is related to the prevalence of Ricardian effects in the absence of frictions in the economy.

The addition of various frictions is generally not sufficient to bring multipliers above one, as findings from various New Keynesian models point out. For instance, in an estimated New Keynesian model for the euro area, Smets and Wouters (2003) find that output multipliers for government spending are positive, but lower than one, and that this also holds with flexible prices and wages. Cogan et al. (2010) find similar results when using the estimated New Keynesian model by Smets and Wouters (2007) on the US economy. When introducing rule-of-thumb households, they find a slightly higher multiplier, but this extension does not have a significant quantitative impact on results. In addition, in their extension of a standard sticky price New Keynesian model with rule-of-thumb households, Galí, López-Salido and Vallés (2007) find that output multipliers are positive, but they exceed one only if labour markets are non-competitive or the share of rule-of-thumb households significantly exceeds the baseline of 50\%. However, there is some agreement in the literature that fiscal multipliers can be large when monetary policy is at the zero- 
lower-bound, which is highly relevant in current economic circumstances in advanced countries. Several studies in the New Keynesian framework conclude that, in a deflationary environment and with monetary policy constrained by the zero lower bound of interest rates, higher government spending financed by higher deficits can yield higher inflationary expectations and consequently lower real interest rates and higher growth (e.g. Christiano, Eichenbaum and Rebelo, 2011; or Woodford, 2011). The finding of large fiscal multipliers in circumstances of accommodative monetary policy, which includes the zero-lower-bound, is also confirmed by Coenen et al. (2012) in their detailed comparison of several structural models used in leading national and international policy institutions.

There is also a wide array of results on the size of the fiscal multiplier and the transmission mechanism in the empirical literature, which is dominated by VAR studies. Depending on the manner in which they impose short-run restrictions to identify fiscal policy shocks, the fiscal VAR literature could be classified in five main categories. First, VARs with recursive identification, e.g. Fatás and Mihov (2001), Monacelli, Perotti and Trigari (2010) and Kim and Roubini (2008). Second, Blanchard-Perotti VARs (BP SVARs), which rely on institutional information to identify shocks, and were originally proposed by Blanchard and Perotti (2002), and used by Perotti (2005) and Marcellino (2006). Third, VARs with sign restrictions on impulse responses, e.g. Mountford and Uhlig (2009). Fourth, event-study VARs, which use exogenous events such as military build-ups to identify fiscal policy shocks, e.g. Ramey and Shapiro (1998) and Ramey (2011). Fifth, narrative VARs, which use legislative records to isolate fiscal policy shocks, e.g. Romer and Romer (2010) and Guajardo, Leigh and Pescatori (2011). In addition, a strand of the recent literature employs panel VARs $\left(\mathrm{PVARs}^{2}\right)$, mostly with recursive identification, to study the effects of fiscal policy shocks in several countries together, e.g. Beetsma and Giuliodori (2011), Bénétrix and Lane (2013), Ilzetzki, Mendoza and Végh (2013) and Almunia et al. (2010).

Studies using recursive identification and BP SVARs tend to find results in line with New Keynesian predictions, whereas studies using the event-study approach are mostly in line with neoclassical predictions regarding the effects of government spending. In addition, studies using sign restrictions or the narrative approach tend to find relatively high tax multipliers, resembling traditional Keynesian predictions. However, there is generally little agreement in the empirical literature where this divergence in results comes from, and whether it stems from the particular type of identification restrictions. On the other hand, there appears to be some agreement that country structural characteristics have an important effect on the size of the fiscal multiplier. For instance, the meta-regression analysis of fiscal VARs by Rusnak (2011) finds that high levels of public debt, high trade openness and high average short-term interest rates all decrease the size of the fiscal multiplier.

\footnotetext{
${ }^{2}$ For an extensive description of PVARs, important methodological issues and their treatment, see Juessen and Linnemann (2010) and Canova and Ciccarelli (2013).
} 


\subsection{METHODOLOGY AND DATA}

Our empirical investigation of the effects of fiscal policy on output and other macroeconomic variables is based on Panel Vector Auto Regression (panel VAR or PVAR), with annual data and recursive identification of policy shocks. An alternative way to study the effects of fiscal policy in European countries, which is dominant in the literature, would be to run country VARs, and then analyse the results in terms of the size of the multiplier or differences by structural characteristics. However, we are unable to use such an approach because of the length and the quality of available fiscal data for European countries, particularly for transition countries. Therefore, we follow the dominant empirical literature in employing the VAR approach, but we pool the countries in one large group (and various sub-samples). This also enables us to utilise one of the main advantages of the panel VAR method, which combines the conventional VAR approach of treating all variables as endogenous with the panel approach, which allows for unobserved country heterogeneity.

We use recursive identification of fiscal policy shocks for two main reasons. First, this is in line with recent studies that use panel VAR to analyse effects of fiscal policy (Beetsma and Giuliodori, 2011; Bénétrix and Lane, 2013; Ilzetzki, Mendoza and Végh, 2013; and Almunia et al., 2010), as well as with the vast majority of studies that use country VARs (Rusnak, 2011; and Gechert and Will, 2012). Second, alternative identification approaches are unfeasible for our aim of study and sample. For instance, the event-study method has been applied only for the US based on defence spending, whereas the narrative method requires the availability of detailed legislative records in order to extract policy shocks. We are also reluctant to use sign restrictions due to drawbacks such as the exclusion of some potentially important features (e.g. "expansionary fiscal contractions") and difficulties in precisely capturing the timing of the shock (Perotti, 2005). Finally, the BP SVAR method requires institutional information on the elasticity of government spending and revenues to output and inflation, which is not available in sufficient detail for our sample.

In our investigation we use annual instead of the quarterly data prevalent in the literature, particularly in country-by-country VARs. Our choice reflects both data availability and recommendations of the relevant empirical literature. It is often argued that, when using fiscal VARs with quarterly data, one should preferably use data collected on an accrual basis, and also use data that are collected at quarterly frequency, i.e. not interpolated from annual data (Perotti, 2005). However, sufficiently long series of non-interpolated quarterly data on an accrual basis are only available for a few developed countries and are unavailable for the wider group of European countries that we are interested in.

The use of annual data has several important implications regarding the anticipation problem and the identification problem, which are essential features of fiscal 
VARs (Alesina and Giavazzi, 2013). While there are discussions on the severity of the consequences of the anticipation problem with quarterly data (e.g. Leeper, Walker and Yang, 2009; and Perotti, 2011), it is often argued that the use of annual data ameliorates the problem, since fiscal policy is less likely to be anticipated one year ahead than one or two quarters ahead (Perotti, 2008). In order to further mitigate the anticipation problem, we also include forward-looking variables such as prices and interest rates in the VAR. This is in line with arguments in the literature (Giannone and Reichlin, 2006; Yang, 2007; and Sims, 2012) that forward-looking variables react contemporaneously to anticipated fiscal policy, implying that they can be used to capture future fiscal policy.

While the use of annual data mitigates the anticipation problem, it might complicate the recursive identification of policy shocks, which relies on decision lags of fiscal policy, as there is usually some delay in the reaction of policymakers to output movements. With recursive identification in a VAR with quarterly data, this is reflected in ordering spending (and sometimes revenues) before output, implying that the former do not react to the latter within the same quarter. While this might be a strong assumption with annual data, there are arguments that support such an approach even with recursive identification (besides data availability reasons). For instance, there is only one important fiscal event in a year (the budget), so policymakers are often constrained from responding quickly to contemporaneous economic movements. Further, Beetsma and Giuliodori (2011) note that with annual data the recovered shocks are more realistic, since new fiscal impulses typically do not appear at quarterly frequency, but once a year when the budget is adopted (and perhaps in mid-year budget supplements). In addition, Beetsma, Giuliodori and Klaassen $(2006,2009)$ provide robustness checks for several countries where non-interpolated quarterly fiscal data are available, and show that recursive identification restrictions for spending shocks in a VAR with annual data are plausible.

The panel VAR specification has several advantages that make it particularly useful for empirical application in macroeconomics. First, it has the advantage of the VAR methodology in treating all the variables as endogenous and interdependent in both a static and a dynamic sense (Canova and Ciccarelli, 2013). It also enables the analysis of a variety of shocks, both endogenous and exogenous. In distinction from time-series VARs, in PVARs a cross-dimensional dimension is added, thus making it possible to exploit the heterogeneous information in cross-section data, but also to increase the sample size in order to eliminate idiosyncratic effects (Gavin and Theodorou, 2005). Related to this, Rebucci (2003) notes that pooling units increases the degrees of freedom and potentially the efficiency of estimates, thus reducing the risk of over-fitting.

While the PVAR combines the features and hence the advantages of VAR and panel methods, it also combines their drawbacks. For instance, it imposes slope homogeneity among units, which could lead to heterogeneity bias and may also 
limit the usefulness of these models for policy advice at the unit, i.e. country level (Georgiadis, 2012). Therefore, in order to account for unobserved heterogeneity, we also introduce country fixed effects (as well as a common time trend), thus following the dominant approach in the empirical literature using PVAR estimation. This means that our baseline model is a panel VAR with fixed effects (PVAR FE).

Due to data limitations, we are forced to maintain homogenous slope coefficients, thus imposing the same dynamics across cross-section units. This approach is criticised by Canova and Ciccarelli (2013), who argue that in order to properly account for heterogeneity one should introduce slope coefficients varying across cross-sections, and possibly across time periods as well. However, besides serious data availability and computational issues, there are counter-arguments that a relatively simple model like ours is applicable when one is interested in common aspects in macroeconomic data and not idiosyncratic effects (Gavin and Theodorou, 2005) and that the PVAR FE model is not too restrictive if one is interested in average policy effects (Georgiadis, 2012). Therefore, we maintain homogenous slope coefficients, but address heterogeneity by using cyclically-adjusted revenues in all our specifications, thus accounting for the part of heterogeneity arising from the differences in automatic stabilizers across countries. We also pay additional attention to heterogeneity by splitting our sample across various structural country characteristics in section 4 .

While the PVAR FE addresses unobserved country heterogeneity, it also leads to the well known problem of biased coefficients in dynamic panels with fixed effects (Nickell, 1981). Nevertheless, the PVAR FE is used in several important studies of fiscal policy with relatively short time dimensions, such as Beetsma, Giuliodori and Klaassen (2006), Beetsma and Giuliodori (2011), Bénétrix and Lane (2013) and Almunia et al. (2010). In addition, the Monte Carlo analysis of various PVAR FE estimators in Juessen and Linnemann (2010) generally supports our choice of this method. Their main results show that the (downward) bias of the PVAR FE coefficients is considerable even when the time dimension is large, whereas GMM estimators perform well in terms of the bias but poorly in terms of the root mean square error, thus leading the authors to recommend the use of bias-corrected PVAR FE. However, using both Monte Carlo analysis and a practical application on a fiscal VAR, Juessen and Linnemann (2010) conclude that although they tend to under-estimate the shock persistence, impulse responses from the PVAR FE are virtually undistinguishable from true impulse responses or from bias-corrected PVAR FE responses at impact and very similar at short horizons $^{3}$. In addition, the Monte Carlo analysis of several estimators by Rebucci (2003), who extends the mean group estimator to the PVAR, shows that slope heterogeneities should be very high in order to justify alternatives to pooled estimators, including PVAR FE, and that the time dimension should be longer than a

\footnotetext{
${ }^{3}$ Although Juessen and Linnemann (2010) recommend the use of bias-corrected PVAR FE, they also warn that bias-correction methods might not be successful in reducing the bias when the time dimension is small, which certainly covers our case of 18 years.
} 
typical macroeconomic data set in order to justify the use of mean group estimators. In other words, the small sample bias may be more detrimental to the mean group estimator than the slope heterogeneity bias is to the PVAR FE estimator (Towbin and Weber, 2013).

Our analysis uses annual data starting in 1995 and ending in 2012 (18 years) and we include the $27 \mathrm{EU}$ member states as of 2012. In the analysis of differences between groups, the EU member states are split in two: the 10 new member states (NMS10) from the Central and Eastern Europe enlargement cohorts of 2004 and 2007, and the 15 old EU member states plus Cyprus and Malta (labelled EU17 or old member states ${ }^{4}$ ). We briefly describe the data when specifying our baseline model in the following sub-section, while detailed data definitions and sources are provided in the appendix.

\subsection{MODEL SPECIFICATION}

In line with the literature, in our specification we include five endogenous variables: government spending, government revenues, GDP, prices and interest rates. These five endogenous variables could be considered as the minimal set of macroeconomic variables necessary to capture dynamic effects of fiscal policy shocks (Fatás and Mihov, 2001). We also include country fixed effects in order to deal with unobserved heterogeneity, as well as a common linear time trend.

We use real GDP as an indicator of output and the GDP deflator as an indicator of price movements. For interest rates we use average nominal three-month money market rates, although in the literature there is some divergence on this issue: numerous studies use short-term rates, while others use long-term interest rates, which are argued to be more relevant for private consumption and investment decisions (Perotti, 2005). However, we are reluctant to take such an approach for two reasons. First, short-term interest rates are better suited for quick reflections of anticipated fiscal policy, which is one of the reasons for the inclusion of interest rates in the VAR. Second, sufficiently long series of long-term interest rates are unavailable for some of the countries in our sample.

When constructing the fiscal variables (appendix), we follow arguments and definitions in Alesina et al. (2002), Caldara and Kamps (2008) and particularly Beetsma, Giuliodori and Klaassen (2006) and Beetsma and Giuliodori (2011). Fiscal variables are defined in real terms, thus facilitating direct inference on the fiscal multiplier since GDP is also defined in real terms. Further, in line with the dominant approach in the literature, we define government spending and revenues net of interest payments, as well as net of social benefits and other transfers. Consequently, government spending is defined as the sum of government consumption (approximately the sum of public wages and purchases of goods and services) and

\footnotetext{
${ }^{4}$ Cyprus and Malta joined EU in 2004 as well, but they are grouped with old EU member states because their economic structure and history makes them much closer to them than to the transition countries of Central and Eastern Europe which joined the EU at the same time or in 2007.
} 
government investment. On the other hand, for revenues we use net-taxes, defined as revenues minus transfers. In particular, we follow the detailed calculations in Beetsma and Giuliodori (2011) and define net-taxes as the sum of indirect taxes, direct taxes, social benefits received and transfers received by the government, minus subsidies, social benefits paid and transfers paid by the government. Further, we follow the arguments and calculations in Beetsma, Giuliodori and Klaassen (2006) and Beetsma and Giuliodori (2011) and cyclically adjust net taxes, while government spending is left unadjusted. We cyclically adjust net taxes by using country elasticities of various components of net taxes to output (EC, 2005) as well as the trend GDP based on Hodrick Prescott filtering.

The structural form of our baseline panel VAR is presented in eq. 1 below. Our analysis covers the period starting in 1995 and ending in $2012(t=1, \ldots, 18)$ and we include the 27 countries that were EU members in $2012(i=1, \ldots, 27)$. The endogenous variables included in the VAR and their ordering is as follows: the log of real government spending $(g)$, the log of real cyclically-adjusted net taxes $(t)$, the $\log$ of real GDP $(y)$, the log of the GDP deflator $(p)$ and average annual threemonth money market interest rates in percent $(r)$. We also include country-specific fixed effects $\left(c_{i}\right)$ and a common time trend $\left(t_{t}\right)$ as exogenous variables. Further, we use 2 lags of each endogenous variable in our VAR. While testing for lag-length in PVARs is not straightforward (Babecký et al., 2012), 2 lags should be sufficient to remove any residual auto-correlation with annual data (and additional checks indicate that baseline results are robust to alternative lag lengths). $D, E, P$ and $H$ capture corresponding coefficients. The vector of orthogonal structural shocks $\varepsilon_{i, t}$ reflects the shocks to each equation in the VAR, with $\operatorname{var}\left(\varepsilon_{i, t}\right)=\Omega$. Finally, the first matrix in Eq. 1 captures contemporaneous relations between endogenous variables, with $\alpha_{\mathrm{nm}}$ elements of the matrix representing the estimated contemporaneous reaction of variable $m$ to shocks in variable $n$, and zero elements reflecting the restrictions of the recursive identification on the contemporaneous relations between variables.

The main implication of this specification is that spending shocks are allowed to have a contemporaneous effect on every variable, but spending is not contemporaneously affected by other shocks. Since we focus on spending shocks ${ }^{5}$, the ordering of the other variables does not matter (Christiano, Eichenbaum and Evans, 1999). The drawback of this ordering is that it implies that cyclicallyadjusted net taxes do not affect spending within a year. While this might seem like too strong a restriction, we rely on this ordering because it is standard in the literature. Besides, additional checks (available on request) show that our impulse responses are robust to the alternative ordering of spending and revenues. Related to this, Beetsma and Giuliodori (2011) argue that spending is mostly predetermined in the budget, whereas changes to spending within the year tend to be less

\footnotetext{
${ }^{5}$ This also implies that, when discussing fiscal multipliers, effectively this applies to government spending
} multipliers. 
important, implying that it is reasonable to order spending first. Output is ordered third, implying that it does not contemporaneously affect spending and net taxes. This restriction is justified by the omission of cyclically-sensitive components from our definition of spending, as well as by the cyclical adjustment of net-taxes. Finally, the ordering of prices and interest rates last is common in the literature, and it implies that these variables react to movements in fiscal variables and to output but do not affect them within the year.

$$
\left(\begin{array}{ccccc}
1 & 0 & 0 & 0 & 0 \\
-\alpha_{g t} & 1 & 0 & 0 & 0 \\
-\alpha_{g y} & -\alpha_{t y} & 1 & 0 & 0 \\
-\alpha_{g p} & -\alpha_{t p} & -\alpha_{y p} & 1 & 0 \\
-\alpha_{g r} & -\alpha_{t r} & -\alpha_{y r} & -\alpha_{p r} & 1
\end{array}\right)\left[\begin{array}{c}
g_{i, t} \\
t_{i, t} \\
y_{i, t} \\
p_{i, t} \\
r_{i, t}
\end{array}\right]=D\left[\begin{array}{c}
g_{i, t-1} \\
t_{i, t-1} \\
y_{i, t-1} \\
p_{i, t-1} \\
r_{i, t-1}
\end{array}\right]+E\left[\begin{array}{c}
g_{i, t-2} \\
t_{i, t-2} \\
y_{i, t-2} \\
p_{i, t-2} \\
r_{i, t-2}
\end{array}\right]+P c_{i}+H t_{t}+\left[\begin{array}{c}
\varepsilon_{i, t}^{g} \\
\varepsilon_{i, t}^{t} \\
\varepsilon_{i, t}^{y} \\
\varepsilon_{i, t}^{p} \\
\varepsilon_{i, t}^{r}
\end{array}\right] \text { Eq. } 1
$$

\section{BASELINE RESULTS AND SUB-SAMPLE ANALYSIS ${ }^{6}$}

We mostly analyse results via impulse responses (and 95\% confidence intervals), as well as impact fiscal multipliers. In order to facilitate the discussion, we standardise the size of the spending shock to be equal to $1 \%$ of GDP, so that we can directly interpret the impulse responses of GDP as the fiscal multiplier.

The results of our baseline specification from eq. 1, which includes the entire sample of 27 EU countries between 1995 and 2012, are presented in figure 1. The spending shock is relatively persistent, as it takes around five years for its effects on spending to die out. At the year of the shock, governments increase net taxes, but this response becomes negative from the following year, presumably as they try to reinforce the effects of spending rises by lowering taxes. The response of real GDP to the spending shock is positive and the fiscal multiplier is around one at the year of the shock and in the following year. While this implies that fiscal policy does stimulate output, its effectiveness is relatively limited, since there are no stronger multiplicative effects beyond the approximately one-for-one response of $\mathrm{GDP}^{7}$. In addition, the fiscal multiplier is halved three years after the shock, when it also becomes insignificant.

The spending shock and the consequent increase in GDP also result in higher inflation, and the rise is significant for three years after the shock. Finally, interest rates fall on impact, while their direction changes the following year, although the response becomes insignificant. While the initial negative response of interest rates is puzzling, we return to it below.

\footnotetext{
${ }^{6}$ We estimate our PVARs using the MATLAB code that has been developed and made public by Georgios Georgiadis, to whom we are grateful for the code and additional advice provided in our correspondence. The code is explained in Georgiadis (2012) and can be downloaded from https://sites.google.com/site/georgiosgeorgiadis111/research. It can also estimate Panel Conditional Homogenous VARs.

${ }^{7}$ The one-for-one response means that a unit increase of government spending corresponds to a unit increase of GDP. If there are no stronger multiplicative effects, this is true by definition, since the definition of GDP also includes government spending (government consumption and investment).
} 


\section{Figure 1}

Impulse responses to a government spending shock of $1 \%$ of real GDP-baseline specification
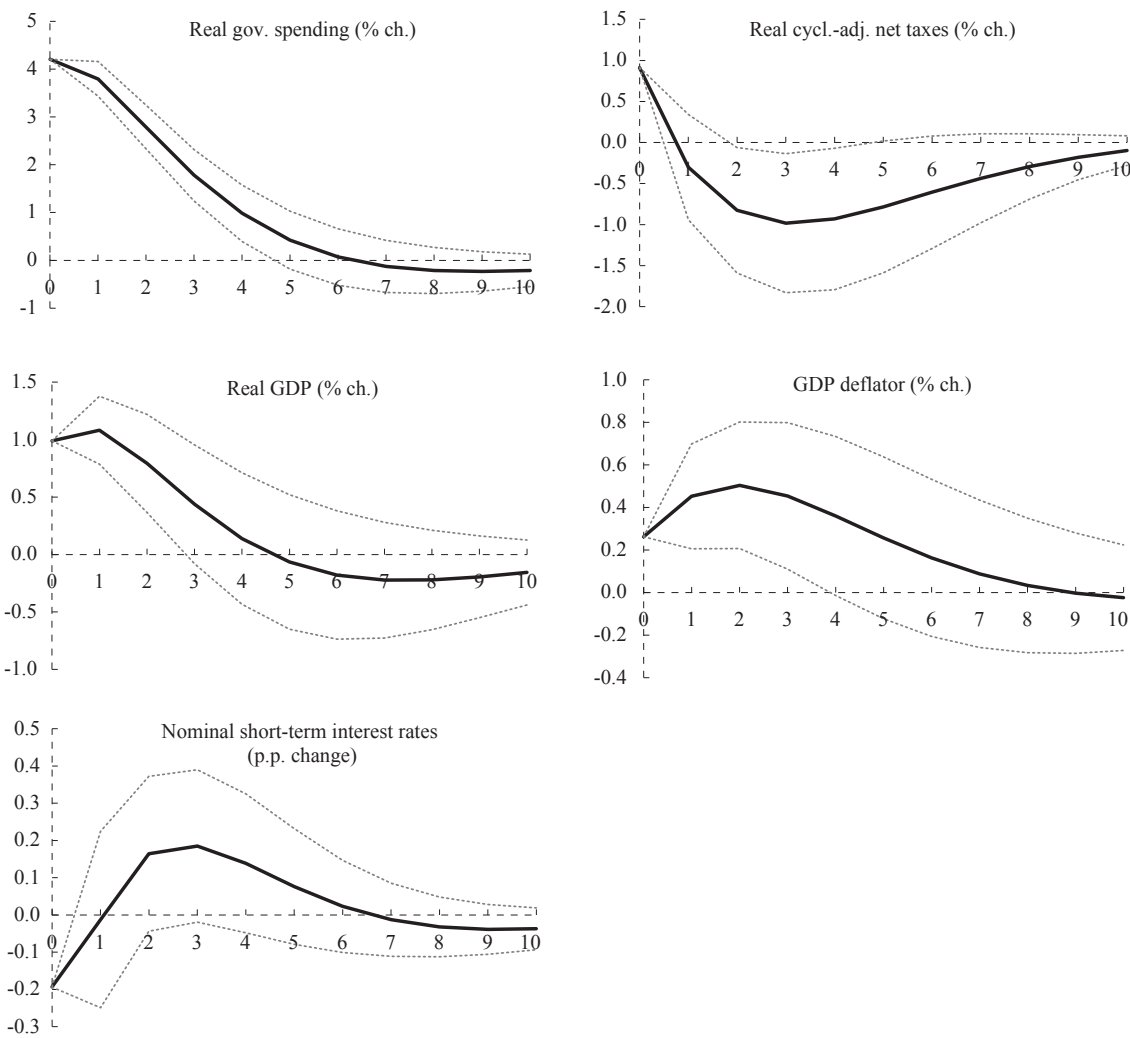

Note: The size of the spending shock in the entire sample and in all sub-samples discussed below equals $1 \%$ of GDP, which is equivalent to around $4 \%$ of government spending in the entire sample.

Table 1 presents results of the forecast error variance decomposition. The left panel indicates that the forecast error variance of GDP is mostly attributable to GDP shocks. In addition, government spending shocks explain $8.4 \%$ of the forecast error variance of GDP on impact, and this effect fades out slowly in the future. On the other hand, the caveats regarding the proper identification of shocks to net taxes notwithstanding, they initially explain only $4.6 \%$ of the forecast error variance of GDP, but their importance rises so as to explain up to around a quarter of the GDP error variance 5 years after the shock. Further, the right panel in table 1 shows that a relatively low share of fluctuations of other variables is attributable to spending shocks. Indeed, spending shocks explain the majority of fluctuations of spending itself, as well as some of the forecast error variance of GDP, but do not explain more than around $3 \%$ of the forecast error variance of the other three variables.

Several additional robustness checks (available on request) indicate that the baseline results are fairly robust to alternative specifications. For instance, results from the baseline specification, which includes country fixed effects and a common linear 
time trend, are robust to the introduction of country-specific linear time trends instead of the common trend, as well as to the omission of the time trend. On the other hand, results between the baseline and the version that omits country fixed effects are considerably different, with the latter responses indicating a permanent level shift of GDP due to a spending shock, which is hardly feasible. This difference compared to the baseline indicates that there is heterogeneity in our sample, so the maintenance of fixed effects is warranted in order to account for unobserved country heterogeneity. Further, baseline results from the second-order PVAR are robust to both a shorter and a longer lag-length by one year, which indicates that there are no severe problems with residual auto-correlation. Finally, we also check the robustness of our results to an alternative ordering of variables: instead of the baseline (spending first, net-taxes second), net-taxes are ordered first and spending second. Despite differences in contemporaneous restrictions arising from the alternative ordering, impulse responses in this case are very similar to the baseline results.

\section{TABLE 1}

Forecast error variance decomposition - baseline specification

Forecast error variance decomposition of GDP

\begin{tabular}{|c|c|c|c|c|}
\hline & At impact & After 1 year & After 3 years & After 5 years \\
\hline \multicolumn{5}{|l|}{ Contributions of shocks to: } \\
\hline Real gov. spending & 8.4 & 7.8 & 5.7 & 4.7 \\
\hline Real cycl.-adj. net taxes & 4.6 & 10.8 & 20.6 & 25.7 \\
\hline Real GDP & 87.0 & 78.9 & 66.1 & 59.9 \\
\hline GDP deflator & 0.0 & 0.7 & 1.9 & 2.1 \\
\hline \multirow{2}{*}{ Nom. short-term int. rates } & 0.0 & 1.7 & 5.7 & 7.6 \\
\hline & 100.0 & 100.0 & 100.0 & 100.0 \\
\hline
\end{tabular}

Contributions of the gov. spending shock

\begin{tabular}{|c|c|c|c|c|}
\hline & At impact & After 1 year & After 3 years & After 5 years \\
\hline \multicolumn{5}{|l|}{ To the FEVD of: } \\
\hline Real gov. spending & 100.0 & 94.5 & 72.7 & 58.6 \\
\hline Real cycl.-adj. net taxes & 1.5 & 0.9 & 1.9 & 2.8 \\
\hline Real GDP & 8.4 & 7.8 & 5.7 & 4.7 \\
\hline GDP deflator & 0.8 & 1.9 & 3.1 & 3.1 \\
\hline Nom. short-term int. rates & 0.5 & 0.4 & 1.0 & 1.1 \\
\hline
\end{tabular}

We proceed by applying the baseline specification of the panel VAR on sub-samples defined by country characteristics. This enables us to analyse whether country structural characteristics influence the effects of fiscal policy on macroeconomic variables. In addition, splitting the sample in various ways also enables us to better address country heterogeneity, since sub-samples consist of more homogenous groups than the entire sample of 27 EU member states.

We first analyse possible differences in fiscal policy effects between the 17 old and 10 new EU member states (EU17 and NMS10 respectively). The comparison in figure 2 shows that the response of spending to its own shock is fairly similar, and it becomes insignificant within 4 to 5 years. On the other hand, there is a completely 
opposite reaction of net taxes. In old EU member states, positive spending shocks are accompanied by lower net taxes as governments try to reinforce higher spending by lowering revenues. In addition, this fall in net taxes is significant for a considerable period into the future. On the other hand, spending shocks in transition countries are accompanied by an increase of net taxes on impact, and the positive reaction of net taxes is significant up to 3 years after the shock, indicating that governments in these countries try to pursue a more disciplined fiscal policy than in old EU member states. Further, the effects of spending shocks on GDP are positive in both old and new EU member states, and in both cases responses become insignificant around 3 years after the shock. However, the fiscal multiplier is higher in transition countries both at impact (1.3 in new and 0.6 in old EU member states) and into the future (e.g., 1 in new and 0.6 in old EU member states 3 years after the shock). Finally, although there are some differences in the dynamics, the reactions of prices and interest rates are fairly similar in the two groups of countries.

\section{Figure 2}

Comparison of impulse responses to a government spending shock of $1 \%$ of real GDP - old and new EU member states
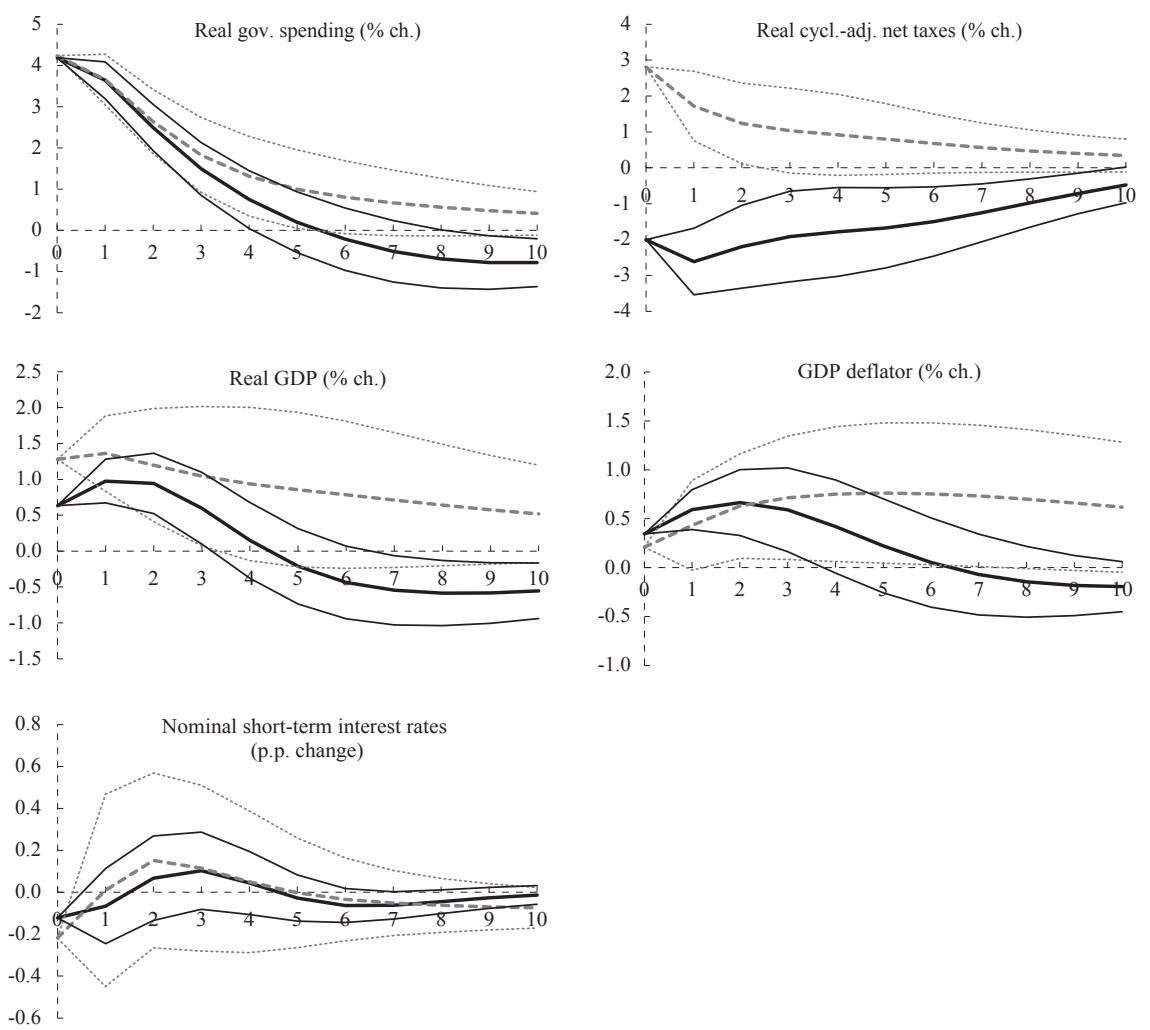

GDP - high-debt and low-debt countries
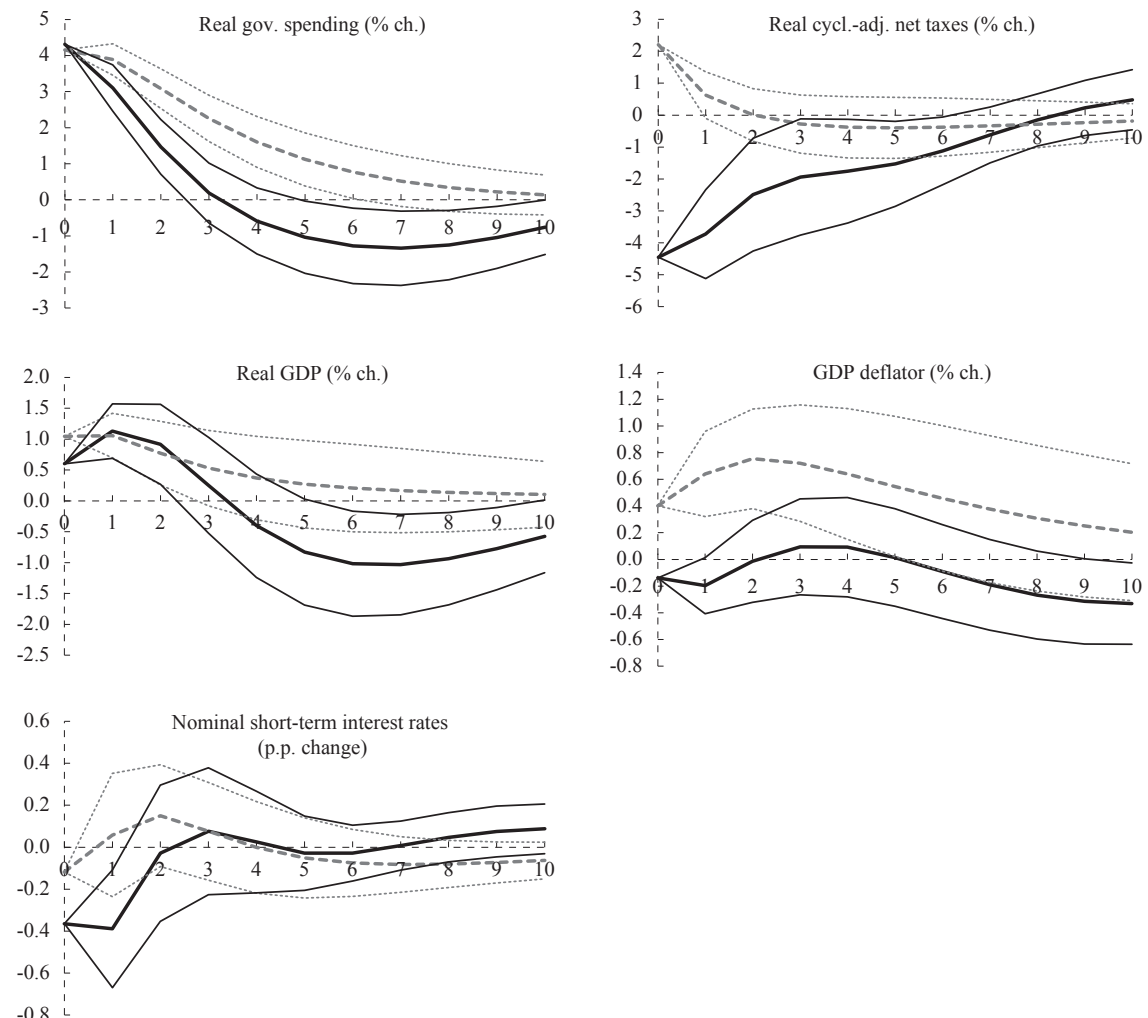

Next we analyse the effects of the level of public debt by using the threshold of the average share of public debt to GDP of $60 \%$ between 1995 and 2012 to split the sample into countries with high and low debt ${ }^{8}$ (figure 3 ). Results indicate that there is indeed a different response to spending shocks in the two groups of countries. First, in countries with lower debt levels, positive spending shocks are followed by higher net-taxes, unlike high-debt countries where higher spending is accommodated by lower taxes, thus potentially further increasing deficits and debt levels. What is more important, the fiscal multiplier is higher in less indebted countries, and this holds both at impact ( 1 in low-debt and 0.6 in high-debt countries) and into the future (e.g., 0.5 in low-debt and 0.3 in high-debt countries 3 years after the shock). This result indicates that the effectiveness of fiscal policy is considerably stronger in low-debt than in high-debt countries, which is in line with a priori expectations and findings in the literature (Rusnak, 2011). Further, spending shocks tend to be followed by higher inflation in low-debt countries, possibly reflecting

\footnotetext{
${ }^{8}$ The threshold of $60 \%$ is in line with the Maastricht criteria for public debt. However, results are similar if
} the threshold is defined as $50 \%$ instead. 
higher demand. On the other hand, the dynamics of the response of interest rates are similar, although there are some differences in magnitude.

\section{Figure 4}

Comparison of impulse responses to a government spending shock of $1 \%$ of real $G D P$ - more and less open countries
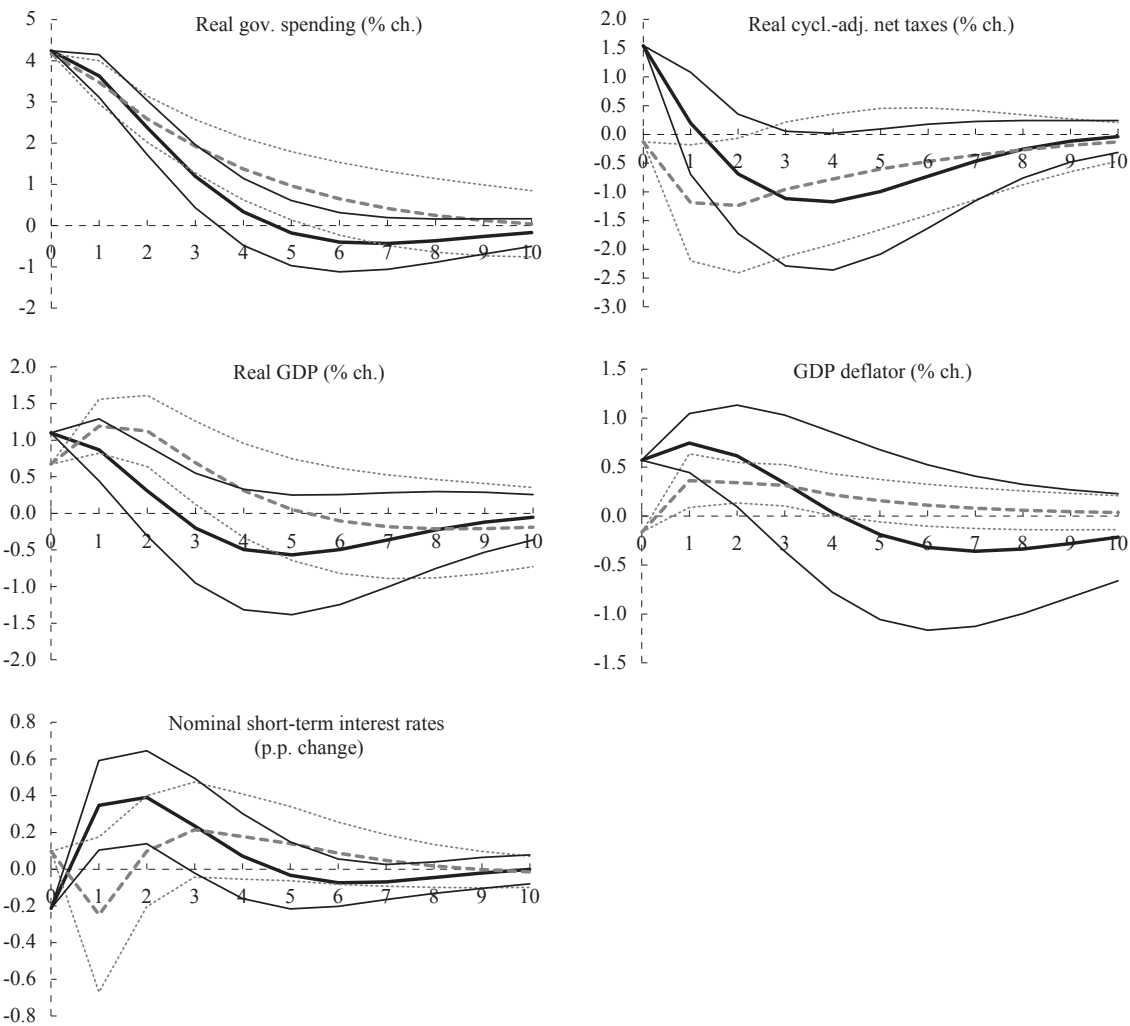

- More open (openness $>50 \%, 14$ countries)

--- Less open (openness $<50 \%, 13$ countries)

Another factor which could influence the effects of fiscal policy is the level of trade openness, since it is expected that, in more open countries, there will be some "leakages" of the positive fiscal shock. In order to analyse this issue, we split our sample into more open and less open countries by using the level of average trade openness to GDP of 50\% between 1995 and 2012 as a threshold ${ }^{9}$. Results in below support the a priori expectation that the effects of fiscal policy differ according to the level of openness. Somewhat surprisingly, on impact the size of the fiscal multiplier is slightly higher in more open than in less open economies (1.1 and 0.7 respectively). However, starting from one year after the shock, the fiscal multiplier is considerably higher in less open economies. In addition, it is also significant for three years after the shock in less open economies, while it

\footnotetext{
${ }^{9}$ Openness is calculated as the share of foreign trade in nominal GDP. Foreign trade is calculated as the sum of nominal exports and imports of goods and services divided by 2 .
} 
becomes insignificant one year after the shock in more open economies. These results indicate that there are considerably more "leakages" in more open economies via the import channel, thus making fiscal policy in these countries less effective. On the other hand, the openness level does not affect the responses of other variables to the spending shock, except for the impact responses.

\section{Figure 5}

Comparison of impulse responses to a government spending shock of $1 \%$ of real GDP - baseline and pre-crisis period
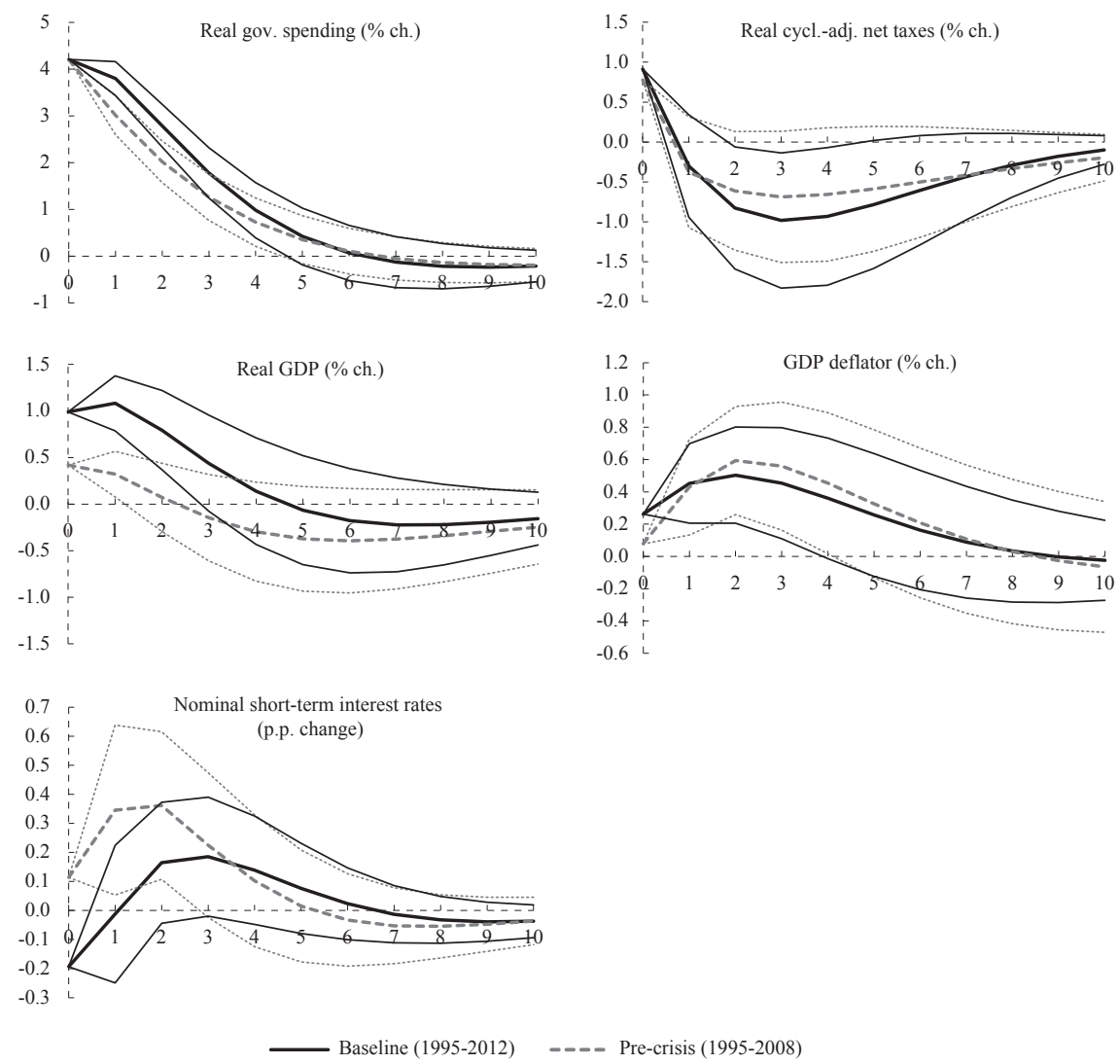

In circumstances of low demand and zero lower bound of nominal policy rates, it is expected that the size of the fiscal multiplier will be higher than in normal circumstances. Therefore, we also investigate whether our baseline results on the effects of fiscal policy shocks in European countries are partially a reflection of the Great Recession. In order to do so, we compare baseline results (1995-2012) to the ones that obtain when shortening the sample for the crisis years, i.e. using only the pre-crisis period between 1995 and 2008. While the shorter sample of 14 years magnifies potential small sample problems, results of this comparison in figure 5 still yield some interesting insights. In the pre-crisis period, the size of the fiscal multiplier is about half the size of the multiplier in the entire period, both on impact 
(0.4 compared to 1) and into the future. In addition, the response of GDP in the precrisis period becomes insignificant only one year after the shock, whereas in the entire period it is significant up to three years after the shock. Overall, these results suggest that fiscal policy is considerably less effective in normal circumstances, while the results for the entire period are driven by the higher effectiveness in the recent crisis years. Further, while the responses of other variables are similar, there are some differences in the response of interest rates. In particular, when using the entire period, interest rates fall on impact, and become insignificant thereinafter, which is somewhat puzzling. However, in the pre-crisis period, the response of interest rates to spending shocks is significantly positive on impact and up to three years after the shock. This difference is an indication that the response of monetary policy in the entire sample might be driven by the crisis years. Indeed, it appears that central banks respond to positive spending shocks with more restrictive policy in normal times, but accommodate fiscal policy shocks during the crisis years.

Before moving to the analysis of the transmission mechanism of fiscal policy and other extensions of our baseline specification, it is useful to summarise the main findings related to differences between results across various sub-samples (table 2 ). The fiscal multiplier in the entire sample is around one on impact and after one year, and declines thereinafter. However, there are considerable differences across country structural characteristics and also when later crisis years are excluded. Overall, the results from this section and particularly the summary in table 2 confirm the suggestion by Spilimbergo, Symansky and Schindler (2009) that fiscal multipliers are country-, time- and circumstance-specific.

\section{TABLE 2}

Fiscal multipliers in the entire sample and in various sub-samples

Size of the fiscal multiplier

\begin{tabular}{|c|c|c|c|c|}
\hline & On impact & $\begin{array}{l}\text { After } \\
1 \text { year }\end{array}$ & $\begin{array}{l}\text { After } \\
\text { 3 years }\end{array}$ & $\begin{array}{l}\text { After } \\
5 \text { years }\end{array}$ \\
\hline Baseline (EU27, 1995-2012) & $1.0 * * *$ & $1.1^{* * *}$ & $0.4 *$ & -0.1 \\
\hline Old EU member states (EU17) & $0.6^{* * *}$ & $1.0 * * *$ & $0.6^{* *}$ & -0.2 \\
\hline New EU member states (NMS10) & $1.3 * * *$ & $1.4 * * *$ & $1.0 * *$ & 0.9 \\
\hline High debt (debt/GDP $>60 \%)$ & $0.6^{* * *}$ & $1.1 * * *$ & 0.3 & $-0.8^{*}$ \\
\hline Low debt (debt/GDP<60\%) & $1.0^{* * *}$ & $1.1^{* * *}$ & $0.5^{*}$ & 0.3 \\
\hline High openness (>50\% of GDP) & $1.1^{* * *}$ & $0.9 * * *$ & -0.2 & -0.6 \\
\hline Low openness ( $<50 \%$ of GDP) & $0.7^{* * *}$ & $1.2^{* * *}$ & $0.7^{* *}$ & 0.1 \\
\hline Pre-crisis (EU27, 1995-2008) & $0.4 * * *$ & $0.3 * *$ & -0.1 & -0.4 \\
\hline
\end{tabular}

Note: The table shows the size of the fiscal multiplier, i.e. the response of real GDP (in \%) to a government spending shock of $1 \%$ of real GDP. ***, ** and * denote significance at the $1 \%, 5 \%$ and $10 \%$ level, respectively.

\section{RESULTS ON THE TRANSMISSION MECHANISM OF FISCAL POLICY}

This section provides extensions of the baseline specification in order to shed some light on the transmission mechanism of fiscal policy. In order to do so, we use various components of GDP and fiscal policy, as well as some additional var- 
iables. In all cases, we start from the baseline specification of our PVAR (eq. 1) and modify it in accordance with the issues we are analysing. We again present only comparison graphs of impulse responses (with corresponding 95\% confidence intervals) for the specifications being analysed, whereas all detailed results are available on request.

We start by augmenting the baseline specification with four additional variables: private consumption, private investment, real wages per employee and total employment ${ }^{10}$. In line with the practice in the literature (e.g. Caldara and Kamps, 2008; and Perotti, 2005), we add one variable at a time to our baseline, which yields four additional specifications with 6 variables ${ }^{11}$. Figure 6 presents the responses of the additional variables in the respective extended 6-variable PVARs. Spending shocks are followed by increases both of private consumption and private investment. While the response of investment is about double that of consumption both at impact and in the future, they both have a similar dynamic and both are significant up to 2 years after the shock. In addition, the rise of private consumption is a reflection of the rise of both real wages and employment following a government spending shock ${ }^{12}$.

\section{Figure 6}

Impulse responses of additional variables to a government spending shock of $1 \%$ of real GDP-extended PVARs with 6 variables
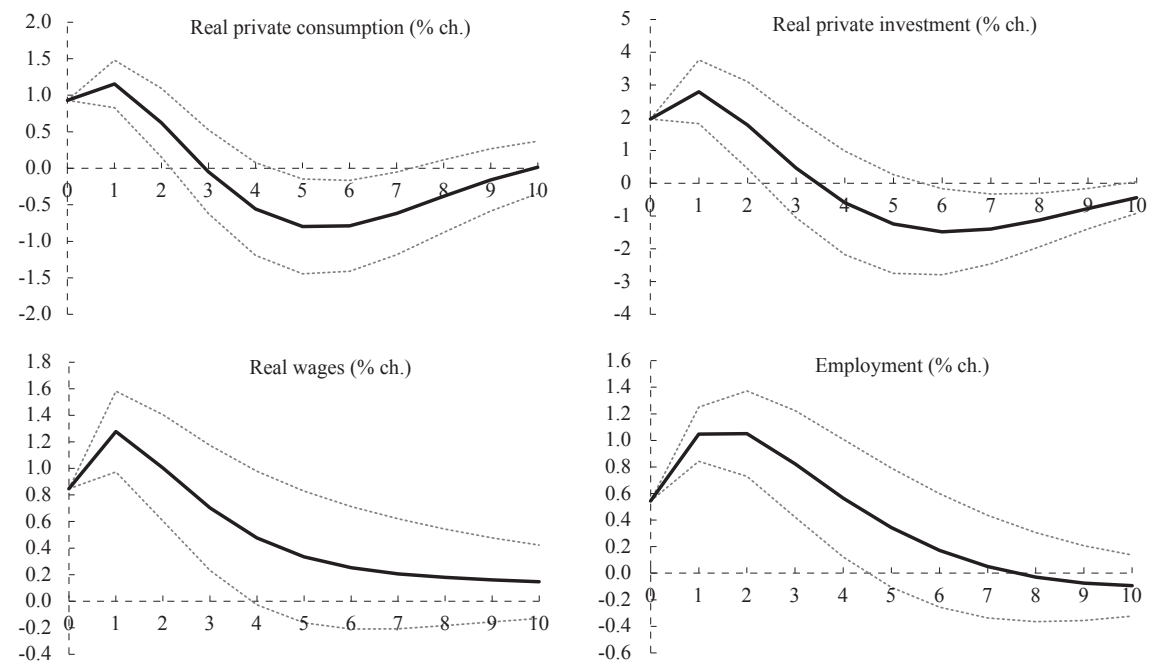

Note: Only responses of the additional variable in each of the four 6-variable PVARs are shown. Complete results of each specification are available on request.

\footnotetext{
${ }^{10}$ Most studies on US data use private sector wages and employment. While such an approach would be consistent with the use of private consumption and investment, data on private sector wages and employment for EU countries are not available from the European Commission AMECO database.

${ }^{11}$ Each new variable is added before GDP. However, as discussed above, the ordering does not matter since we are interested only in the effects of spending shocks, which are ordered first.

${ }^{12}$ When splitting the sample into old and new EU member states, we find similar dynamics and signs of the responses in the two groups, although there are some differences in the strength of the responses. In particular, the rise of consumption, wages and employment is stronger in new EU member states, and this holds both at impact and into the future. These results are available on request.
} 
The extension of the baseline specification with these variables also makes it possible to analyse whether effects of fiscal policy are in line with Real Business Cycle (RBC) or New Keynesian predictions. Both groups of theories predict that government spending shocks cause higher output. Related to this, our previous finding of rising output in response to spending shocks in the baseline specification is in line with the vast majority of other empirical studies as well as predictions of the two main theories. Further, our finding of rising private consumption, real wages and employment is in line with predictions both from extended RBC models with monopolistic competition and "deep habits" in the consumption of individual goods (Ravn, Schmitt-Grohe and Uribe, 2006) and extended New Keynesian models with rule-of-thumb consumers (Galí, López-Salido and Vallés, 2007).

\section{Figure 7}

Impulse responses of GDP to a shock of $1 \%$ of real GDP in various spending components
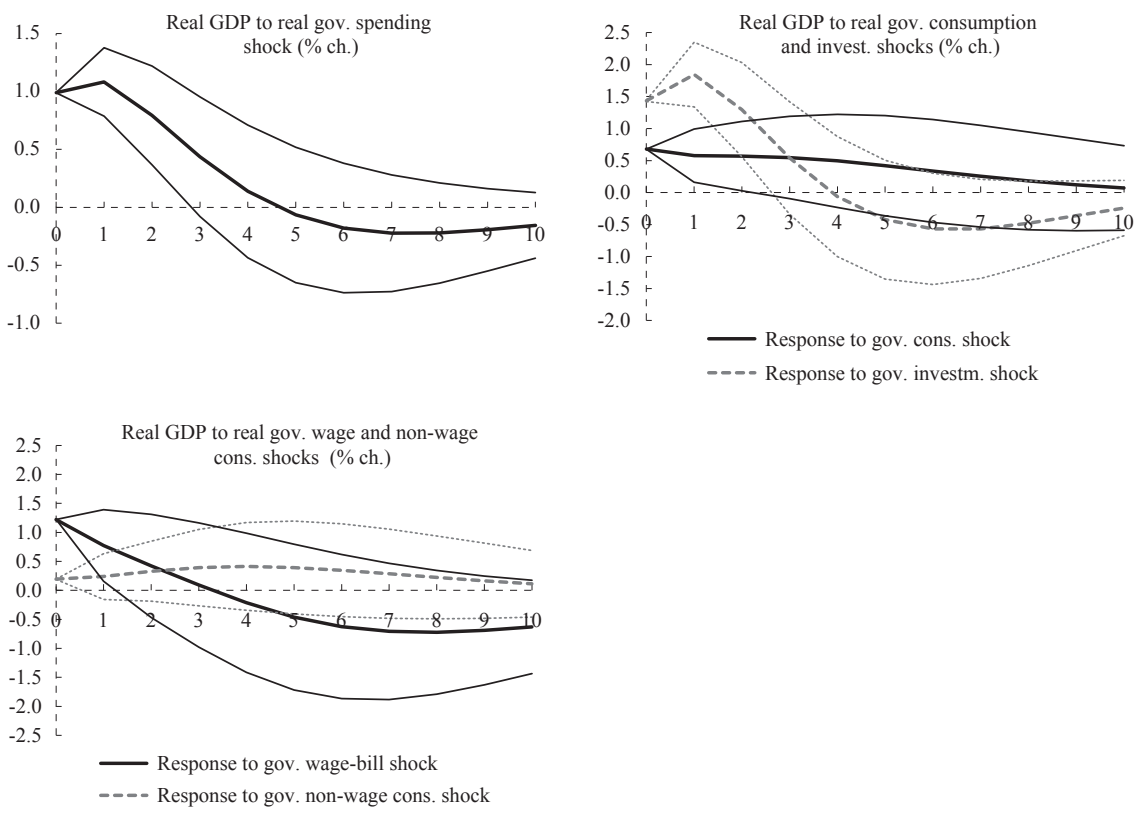

We proceed by analysing the effects of the two components of government spending: consumption and investment. We also consider the two components of government consumption: the wage bill and the non-wage consumption (i.e. goods and services). In the baseline specification, we replace real government spending with its components, one at a time, and present the responses of GDP to shocks of $1 \%$ of GDP of various components in figure 7 . Results show that government investment is the more effective tool in stimulating output than government consumption. Among the components of government consumption, government wage bill shocks are more effective than government non-wage consumption shocks up to two years after the shock, although in both cases the response becomes insignificant rather quickly. Overall, these results indicate that, if the aim is to stimulate 
output, the most effective way to do so is by increasing government investment. If government consumption is used, the effects of government employees' wages are somewhat larger than those of non-wage consumption ${ }^{13}$.

\section{Figure 8}

Comparison of impulse responses to a government spending shock of $1 \%$ of real GDP - baseline and baseline extended with debt/GDP as endogenous variable

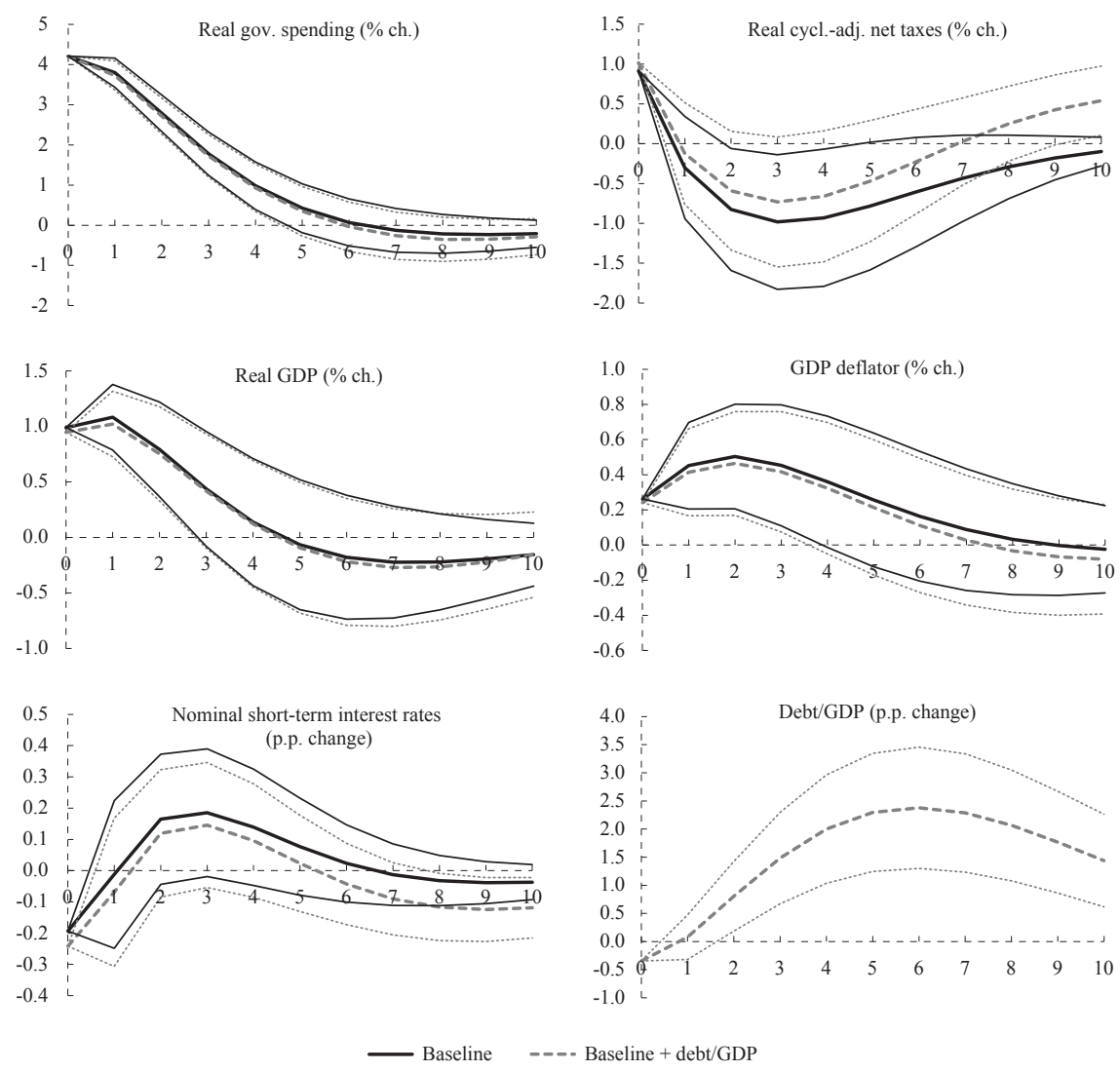

Next we analyse the robustness of our baseline results for the entire sample to the inclusion of the public debt ratio in the specification. Public debt is not usually included in fiscal VARs, which has been criticised by Favero and Giavazzi (2007) since a fiscal shock is expected to constrain future revenues and spending due to the intertemporal budget constraint. Consequently, they argue that results of standard fiscal VARs may be biased due to the omission of debt, and recommend that the analysis of fiscal shocks should take into account debt dynamics and allow

\footnotetext{
${ }^{13}$ We also considered the effects of various government spending components on private consumption and investment separately by replacing GDP with private consumption and private investment, and then replacing government spending with its components one at a time. Overall, results indicate that fiscal policy works mostly via its effects on private investment, which normally appears to be more responsive, whereas responses of private consumption are lower, in line with the expected higher inertia in household consumption. These results are available on request.
} 
for possible feedback from debt to fiscal and other variables. Therefore, we augment our baseline specification for the entire sample with the share of public debt to GDP as an endogenous variable (ordered last). Results in figure 8 indicate that baseline responses of other variables to a government spending shock are robust to the inclusion of the debt level. This also holds for the response of interest rates, which is opposite to findings by Favero and Giavazzi (2007) that in the US interest rates respond differently to spending shocks when debt is included in the VAR. In addition, the debt/GDP ratio itself slightly falls on impact in response to a spending shock, probably reflecting the rise of net taxes and of GDP on impact. However, there is a significant increase in the debt/GDP ratio of up to 2 percentage points in the future and this response dies out rather slowly. Overall, these results on the response of public debt suggest that spending shocks have a considerable deteriorating effect on fiscal sustainability. Indeed, in the wake of spending shocks, the rise of spending is quite persistent, unlike the positive response of nettaxes, which dies out considerably faster, thus giving rise to higher budget deficits and consequently higher debt levels.

\section{Figure 9}

Comparison of impulse responses of GDP to a government spending shock of $1 \%$ of real GDP with and without debt/GDP - old and new EU member states
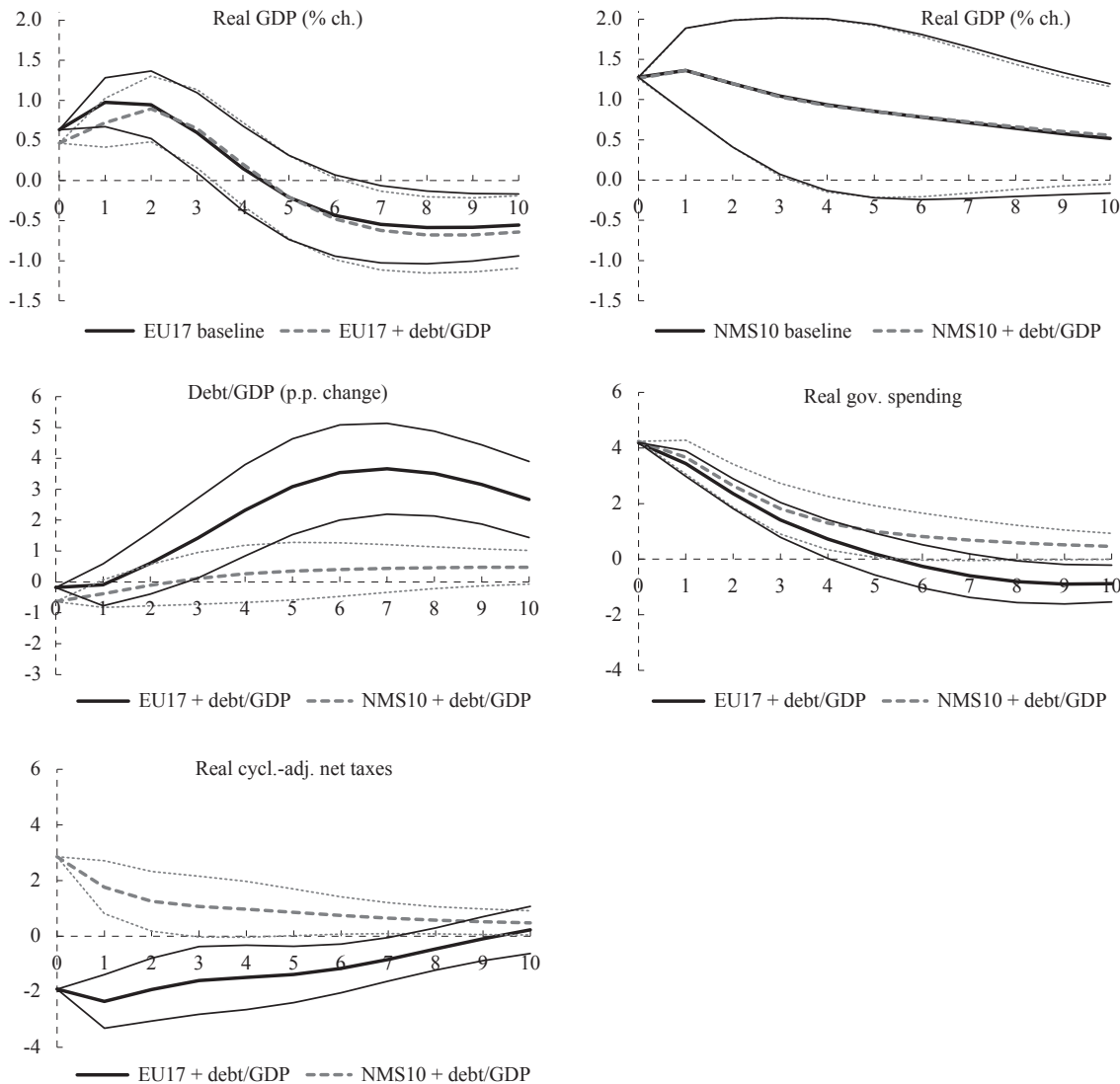
We carry out the same exercise, but now we split the sample to old and new EU member states. Results in figure 9 below indicate that baseline responses of GDP to spending shocks are robust to the inclusion of debt in both country groups. In addition, the conclusion from the baseline that fiscal multipliers are higher in new than in old member states holds when debt is added. Finally, it appears that fiscal sustainability is stronger in new than in old member states, since government spending shocks result in a low and insignificant response of debt in new member states, unlike old member states where spending shocks are followed by considerably higher debt levels. Results also indicate that this difference in the response of debt levels is related to the response of net-taxes in old and new EU member states, which was discussed above. Indeed, in new EU member states, government spending shocks are followed by higher net-taxes. On the other hand, higher spending in old EU member states is accommodated by lower taxes, and consequently debt levels are higher, thus giving rise to concerns about debt sustainability.

\section{CONCLUSIONS AND POLICY IMPLICATIONS}

This study provides an empirical analysis of the effects of fiscal policy on output and other macroeconomic variables in EU countries between 1995 and 2012. The empirical investigation uses panel VAR with fixed effects and recursive identification of fiscal policy shocks. We find that higher spending does result in higher GDP in the entire sample, but the size of the fiscal multiplier does not exceed one, implying that the effects of fiscal policy are relatively limited. In addition, the effectiveness of fiscal policy in the entire sample appears to reflect the crisis period, when it was in fact the only policy tool available due to the zero lower bound of nominal interest rates in most countries. This implies that, once the economic recovery becomes sustained, it is likely that fiscal multipliers will fall back to their common levels in more "normal" circumstances, i.e. positive but below one. Consequently, in such a case, preference should be given to monetary policy in attempts to affect short-term output movements, as well as to structural reforms when trying to affect long-term output.

Our analysis also indicates that policy-makers should pay particular attention to structural characteristics of their countries when trying to affect output via government spending. For instance, expansionary spending in transition countries is more effective in stimulating output than in old EU member states. In addition, higher spending in transition countries is also accompanied by higher taxes, which consequently leads to a relatively stable path of public debt. Our results imply that this practice of expansionary spending and higher taxes should also be used in old EU member states in order to prevent the worrying trend of rising debt levels in the wake of higher spending, without at the same time jeopardising the positive effects of higher spending on output. Further, policy-makers in countries with high public debt and high trade openness should refrain from using government spending to stimulate output, since such a policy is largely ineffective. 
The analysis of the transmission mechanism of fiscal policy suggests that spending shocks cause rises in both private investment and consumption, with the latter being supported by higher real wages and higher employment. This is in line with findings in most other empirical studies, and also consistent with predictions from extensions of both RBC and New Keynesian models. Findings in this part also suggest that fiscal policy is more effective when implemented via government investment than via government consumption. Further, the introduction of the share of debt in GDP in the model in order to account for intertemporal budget constraints and debt feedbacks yields some worrying implications for fiscal sustainability. In particular, spending shocks are followed by rising debt levels in old EU member states, which could be related well to the recent European debt crisis.

\section{Disclosure statement}

No potential conflict of interest was reported by the author. 


\section{DATA SOURCES AND DEFINITIONS}

We follow arguments and definitions in Alesina et al. (2002), Caldara and Kamps (2008) and particularly Beetsma, Giuliodori and Klaassen (2006), Beetsma and Giuliodori (2011) and Suyker (1999). In order to facilitate the exposition of formulas, here we first present variable names alongside their description and sources, and then the formulas to calculate the variables that are used in the empirical investigation.

Unless noted otherwise, absolute amounts are in nominal terms; variables actually used in estimation in the paper are in bold; "ca" refers to cyclically-adjusted variables using trend GDP based on the Hodrick-Prescott filter; AMECO refers to the AMECO Database of the European Commission (May 2013).

\begin{tabular}{|c|c|c|}
\hline Variable name & $\begin{array}{l}\text { Variable description (original titles for variables } \\
\text { not calculated by formula) }\end{array}$ & Source \\
\hline ca_gov_nt_real & Real cyclically-adjusted net-taxes & Formula \\
\hline ca_gov_rev & Cyclically-adjusted government revenues & Formula \\
\hline ca_gov_rev_real & Real cyclically-adjusted government revenues & Formula \\
\hline ca_gov_tran & Cyclically-adjusted government transfers & Formula \\
\hline ca_gov_tran_real & Real cyclically-adjusted government transfers & Formula \\
\hline cit_dir & Share of corporate income tax in direct taxes & Formula \\
\hline comp_avg & Nominal compensation per employee: total economy & AMECO \\
\hline comp_avg_real & Real wages & Formula \\
\hline comp_gg & $\begin{array}{l}\text { Compensation of employees: general government :- } \\
\text { ESA } 1995\end{array}$ & AMECO \\
\hline comp_gg_cons & Real government wage bill & Formula \\
\hline debt & $\begin{array}{l}\text { General government consolidated gross debt :- } \\
\text { excessive deficit procedure (based on ESA 1995) and } \\
\text { former definition (linked series) }\end{array}$ & AMECO \\
\hline debt/ngdp & Debt/GDP ratio & Formula \\
\hline def_gc & $\begin{array}{l}\text { Price deflator total final consumption expenditure of } \\
\text { general government, } 2005=100\end{array}$ & AMECO \\
\hline def_gdp & $\begin{array}{l}\text { GDP deflator (price deflator gross domestic product } \\
\text { at market prices, 2005 }=100 \text { ) }\end{array}$ & AMECO \\
\hline def_gfef & $\begin{array}{l}\text { Price deflator gross fixed capital formation: total } \\
\text { economy, } 2005=100\end{array}$ & AMECO \\
\hline el_cit & $\begin{array}{l}\text { Elasticity of corporate income tax with respect to the } \\
\text { output gap }\end{array}$ & EC (2005) \\
\hline el_dir & Elasticity of direct taxes with respect to the output gap & EC (2005) \\
\hline el_ind & Elasticity of indirect taxes with respect to the output gap & EC (2005) \\
\hline el_pit & $\begin{array}{l}\text { Elasticity of personal income tax with respect to the } \\
\text { output gap }\end{array}$ & EC (2005) \\
\hline el_prexp & $\begin{array}{l}\text { Elasticity of current primary expenditures with respect } \\
\text { to the output gap }\end{array}$ & EC (2005) \\
\hline el_soc & $\begin{array}{l}\text { Elasticity of social contributions with respect to the } \\
\text { output gap }\end{array}$ & EC (2005) \\
\hline empl & $\begin{array}{l}\text { Employment (employees, persons: all domestic } \\
\text { industries; national accounts) }\end{array}$ & AMECO \\
\hline
\end{tabular}




\begin{tabular}{|c|c|c|}
\hline expend_curr & $\begin{array}{l}\text { Total current expenditure: general government :- } \\
\text { ESA } 1995\end{array}$ & AMECO \\
\hline expend_curr_pr & Current primary expenditures & Formula \\
\hline gc & $\begin{array}{l}\text { Final consumption expenditure of general government } \\
\text { at current prices }\end{array}$ & AMECO \\
\hline gc_cons & Real government consumption & Formula \\
\hline gc_nw_cons & Real government non-wage consumption & Formula \\
\hline gdp_cons & $\begin{array}{l}\text { Real GDP (gross domestic product at } 2005 \text { market } \\
\text { prices) }\end{array}$ & AMECO \\
\hline gdp_trend & $\begin{array}{l}\text { Trend gross domestic product at } 2005 \text { market prices } \\
\text { (based on the Hodrick-Prescott filter) }\end{array}$ & AMECO \\
\hline gfef_gg & $\begin{array}{l}\text { Gross fixed capital formation at current prices: general } \\
\text { government }\end{array}$ & AMECO \\
\hline gfcf_gg_cons & Real government investment & Formula \\
\hline gfef_priv & $\begin{array}{l}\text { Gross fixed capital formation at current prices: private } \\
\text { sector }\end{array}$ & AMECO \\
\hline gfef_priv_cons & Real private investments & Formula \\
\hline gov_spend_real & Real government spending & Formula \\
\hline gov_tran & Government transfers & Formula \\
\hline inter & Interest: general government :- ESA 1995 & AMECO \\
\hline ir_st & $\begin{array}{l}\text { Nominal short-term interest rates } \\
\text { (note: the series corresponds to nominal 3-month } \\
\text { money market interest rates) }\end{array}$ & $\begin{array}{l}\text { AMECO } \\
\text { and } \\
\text { IMF IFS }\end{array}$ \\
\hline $\mathbf{m}$ & $\begin{array}{l}\text { Imports of goods and services at current prices } \\
\text { (national accounts) }\end{array}$ & AMECO \\
\hline ngdp & $\begin{array}{l}\text { Nominal GDP (gross domestic product at current } \\
\text { market prices) }\end{array}$ & AMECO \\
\hline open & Trade openness & Formula \\
\hline pc_cons & $\begin{array}{l}\text { Real private consumption (private final } \\
\text { consumption expenditure at } 2005 \text { prices) }\end{array}$ & AMECO \\
\hline pit_dir & Share of personal income tax in direct taxes & EC (2005) \\
\hline prop_paid & Property income, payable & Eurostat \\
\hline prop_rec & Property income, receivable & Eurostat \\
\hline rev_curr & Total current revenue: general government :- ESA 1995 & AMECO \\
\hline soc_ben_paid & $\begin{array}{l}\text { Social benefits other than social transfers in kind: } \\
\text { general government :- ESA } 1995\end{array}$ & AMECO \\
\hline soc_rec & $\begin{array}{l}\text { Social contributions received: general government :- } \\
\text { ESA } 1995\end{array}$ & AMECO \\
\hline subs & Subsidies: general government :- ESA 1995 & AMECO \\
\hline tax_dir & $\begin{array}{l}\text { Current taxes on income and wealth (direct taxes): } \\
\text { general government :- ESA } 1995\end{array}$ & AMECO \\
\hline tax_ind & $\begin{array}{l}\text { Taxes linked to imports and production (indirect taxes): } \\
\text { general government :- ESA } 1995\end{array}$ & AMECO \\
\hline trpg & Other current transfers paid by government & Formula \\
\hline trrg & Other current transfers received by government & Formula \\
\hline $\mathbf{x}$ & $\begin{array}{l}\text { Exports of goods and services at current prices } \\
\text { (National accounts) }\end{array}$ & AMECO \\
\hline
\end{tabular}


Expenditures

gov_spend_real $=$ gc/def_gc*100 + gfcf_gg/def_gfcf*100

gc_cons $=$ gc $/$ def_gc* 100

gfcf_gg_cons $=$ gfcf_gg/def_gfcf*100

expend_curr_pr = expend_curr - inter

comp_gg_cons $=$ comp_gg/def_gc*100

gc_nw_cons $=\left(\mathrm{gc}-\mathrm{comp} \_\right.$empl_gg $) / \mathrm{def} \_g \mathrm{c} * 100$

Revenues ("ca" refers to cyclically-adjusted variables using trend GDP based on

the Hodrick-Prescott filter)

ca_gov_nt_real = ca_gov_rev_real - ca_gov_tran_real

ca_gov_rev_real $=$ ca_gov_rev/def_gdp*100

ca_gov_tran_real $=$ ca_gov_tran/def_gdp*100

ca_gov_rev $=$ ca_tax_dir + ca_tax_ind + ca_soc_rec + ca_trrg

ca_tax_dir $=\overline{t a x} \_$dir* $\left(g d p \_t r e n d / g d p \_c o n s\right) \wedge-\overline{e l}$ dir

ca_tax_ind $=$ tax_ind*(gdp_trend $\left./ g d p \_c o n s\right)^{\wedge}$ el_ind

ca_soc_rec $=$ soc_rec* $\left(\right.$ gdp_trend $\left./ g d p \_c o n s\right) \wedge e l \_s o c$

ca_trrg $=\operatorname{trrg} *\left(g d p \_t r e n d / g d p \_c o n s\right) \wedge(-1 *$ el_prexp*trrg/expend_curr_pr $)$

trrg $=$ rev_curr - prop_rec - tax_ind - tax_dir - soc_rec

ca_gov_tran $=$ gov_tran $*\left(g d p \_t r e n d / g d p \_c o n s\right)^{\wedge}\left(e l \_p r e x p^{*}\right.$ gov_tran/expend curr_pr)

gov_tran $=$ subs + soc_ben_paid + trpg

$\operatorname{trpg}=$ expend_curr + cons_fix_gg - gc - subs - soc_ben_paid - prop_paid

el_dir $=$ el_pit $*($ pit_dir $)+$ el_cit $*($ cit_dir $)$

\section{Other variables}

gfcf_priv_cons $=$ gfcf_priv/def_gfcf*100

comp_avg_real $=$ comp_avg/def_gdp $* 100$

debt/ngdp $=$ debt/ngdp

open $=((x+m) / 2) / n g d p$ 


\section{REFERENCES}

1. Aiyagari, S. R., Christiano, L. J., and Eichenbaum, M., 1992. The output, employment, and interest rate effects of government consumption. Journal of Monetary Economics, 30(1), pp. 73-86. doi: 10.1016/0304-3932(92)90045-4

2. Alesina, A. [et al.], 2002. Fiscal policy, profits, and investment. American Economic Review, 92(3), pp. 571-589. doi: 10.1257/00028280260136255

3. Alesina, A. and Giavazzi, F., 2013. Introduction. In: Alesina, A. and Giavazzi, F., eds. Fiscal policy after the financial crisis. Chicago: University of Chicago Press, pp. 1-18. doi: 10.7208/chicago/9780226018584.003.0001

4. Almunia, M. [et al.], 2010. From Great Depression to Great Credit Crisis: Similarities, differences and lessons. Economic Policy, 25(62), pp. 219-265. doi: 10.1111/j.1468-0327.2010.00242.x

5. Babecký, J. [et al.], 2012. Leading indicators of crisis incidence: Evidence from developed countries. European Central Bank Working Paper, No. 1486.

6. Baxter, M. and King, R. G., 1993. Fiscal policy in general equilibrium. American Economic Review, 83(3), pp. 315-334.

7. Beetsma, R. and Giuliodori, M., 2011. The effects of government purchases shocks: Review and estimates for the EU. The Economic Journal, 121(550), pp. F4-F32. doi: 10.1111/j.1468-0297.2010.02413.x

8. Beetsma, R., Giuliodori, M. and Klaassen, F., 2006. Trade spill-overs of fiscal policy in the European Union: A panel analysis. Economic Policy, 21(48), pp. 639-687. doi: 10.1111/j.1468-0327.2006.00168.x

9. Beetsma, R., Giuliodori, M. and Klaassen, F., 2009. Temporal aggregation and SVAR identification, with an application to fiscal policy. Economics Letters, 105(3), pp. 253-255. doi: 10.1016/j.econlet.2009.08.010

10. Bénétrix, A. S. and Lane, P. R., 2013. Fiscal shocks and the real exchange rate. International Journal of Central Banking, 9(3), pp. 6-37.

11. Blanchard, O. J. and Perotti, R., 2002. An empirical characterization of the dynamic effects of changes in government spending and taxes on output. The Quarterly Journal of Economics, 117(4), pp. 1329-1368. doi: 10.1162/ 003355302320935043

12. Caldara, D. and Kamps, C., 2008. What are the effects of fiscal shocks? A VAR-based comparative analysis. European Central Bank Working Paper, No. 877.

13. Canova, F. and Ciccarelli, M., 2013. Panel vector autoregressive models: A survey. European Central Bank Working Paper, No. 1507.

14. Christiano, L. J., Eichenbaum, M. and Rebelo, S., 2011. When is the government spending multiplier large? Journal of Political Economy, 119(1), pp. 78-121. doi: $10.1086 / 659312$

15. Christiano Christiano, L. J., Eichenbaum, M. and Evans, C. L., 1999. Monetary policy shocks: What have we learned and to what end? In: Taylor, J. B. and Woodford, M., eds. Handbook of Macroeconomics, Volume 1. Amsterdam: Elsevier, pp. 65-148. doi: 10.1016/s1574-0048(99)01005-8

16. Coenen, G. [et al.], 2012. Effects of fiscal stimulus in structural models. American Economic Journal: Macroeconomics, 4(1), pp. 22-68. doi: 10.1257/mac.4.1.22 
17. Cogan, J. F. [et al.], 2010. New Keynesian versus old Keynesian government spending multipliers. Journal of Economic Dynamics and Control, 34(3), pp. 281-295. doi: 10.1016/j.jedc.2010.01.010

18. EC, 2005. New and updated budgetary elasticities for the EU budgetary surveillance. Information note for the Economic and Policy Committee, ECFIN/B/6(2005)REP54508, Directorate-General for Economic and Financial Affairs, European Commission.

19. Fatás, A. and Mihov, I., 2001. The effects of fiscal policy on consumption and employment: Theory and evidence. Centre for Economic Policy Research Discussion Paper, No. 2760.

20. Favero, C. and Giavazzi, F., 2007. Debt and the effects of fiscal policy. NBER Working Paper, No. 12822.

21. Galí, J., López-Salido, J. D. and Vallés, J., 2007. Understanding the effects of government spending on consumption. Journal of the European Economic Association, 5(1), pp. 227-270. doi: 10.1162/JEEA.2007.5.1.227

22. Gavin, W. T. and Theodorou, A. T., 2005. A common model approach to macroeconomics: Using panel data to reduce sampling error. Journal of Forecasting, 24(3), pp. 203-219. doi: 10.1002/for.954

23. Gechert, S. and Will, H., 2012. Fiscal multipliers: A meta regression analysis. Institut für Makroökonomie und Konjunkturforschung (IMK) Working Paper, No. 97/2012.

24. Georgiadis, G., 2012. The panel conditionally homogenous vectorautoregressive model. MPRA Paper, No. 37755.

25. Giannone, D. and Reichlin, L., 2006. Does information help recovering structural shocks from past observations? Journal of the European Economic Association, 4(2-3), pp. 455-465. doi: 10.1162/jeea.2006.4.2-3.455

26. Guajardo, J., Leigh, D. and Pescatori, A., 2011. Expansionary austerity new international evidence. International Monetary Fund Working Paper, No. 11/158.

27. Hebous, S., 2011. The effects of discretionary fiscal policy on macroeconomic aggregates: A reappraisal. Journal of Economic Surveys, 25(4), pp. 674-707. doi: 10.1111/j.1467-6419.2010.00659.x

28. Hemming, R., Kell, M. and Mahfouz, S., 2002. The effectiveness of fiscal policy in stimulating economic activity - A review of the literature. International Monetary Fund Working Paper, No. 02/208.

29. Ilzetzki, E., Mendoza, E. G. and Végh, C. A., 2013. How big (small?) are fiscal multipliers? Journal of Monetary Economics, 60(2), pp. 239-254. doi: 10.1016/ j.jmoneco.2012.10.011

30. Juessen, F. and Linnemann, L., 2010. Estimating panel VARs from macroeconomic data: Some Monte Carlo evidence and an application to OECD public spending shocks. SFB 823 Discussion Paper, No. 24/2010.

31. Kim, S. and Roubini, N., 2008. Twin deficit or twin divergence? Fiscal policy, current account, and real exchange rate in the U.S. Journal of International Economics, 74(2), pp. 362-383. doi: 10.1016/j.jinteco.2007.05.012

32. Leeper, E. M., 2010. Monetary science, fiscal alchemy. Proceedings - Economic Policy Symposium - Jackson Hole, 2010, pp. 361-434. doi: 10.3386/w16510 
33. Leeper, E. M., Walker, T. B., and Yang, S.-C. S., 2009. Fiscal foresight and information flows. NBER Working Paper, No. 14630.

34. Linnemann, L. and Schabert, A., 2003. Fiscal policy in the new neoclassical synthesis. Journal of Money, Credit and Banking, 35(6), pp. 911-929. doi: $10.1353 / \mathrm{mcb} .2003 .0045$

35. Linnemann, L., 2006. The effect of government spending on private consumption: A puzzle?. Journal of Money, Credit, and Banking, 38(7), pp. 1715-1735. doi: 10.1353/mcb.2006.0094

36. Marcellino, M., 2006. Some stylized facts on non-systematic fiscal policy in the euro area. Journal of Macroeconomics, 28(3), pp. 461-479. doi: 10.1016/ j.jmacro.2004.11.003

37. Monacelli, T., Perotti, R. and Trigari, A., 2010. Unemployment fiscal multipliers. Journal of Monetary Economics, 57(5), pp. 531-553. doi: 10.1016/ j.jmoneco.2010.05.009

38. Mountford, A. and Uhlig, H., 2009. What are the effects of fiscal policy shocks? Journal of Applied Econometrics, 24(6), pp. 960-992. doi: 10.1002/jae.1079

39. Nickell, S. J., 1981. Biases in dynamic models with fixed effects. Econometrica, 49(6), pp.1417-1426. doi: 10.2307/1911408

40. Perotti, R., 2005. Estimating the effects of fiscal policy in OECD countries. Centre for Economic Policy Research Discussion Paper, No. 4842.

41. Perotti, R., 2008. In search of the transmission mechanism of fiscal policy. In: Acemoglu, D., Rogoff, K. and Woodford, M., eds. NBER Macroeconomics Annual 2007, Volume 22. pp. 169-226. Chicago: University of Chicago Press.

42. Perotti, R., 2011. Expectations and fiscal policy: An empirical investigation. Innocenzo Gasparini Institute for Economic Research (IGIER) Working Paper, No. 429.

43. Ramey, V. A. and Shapiro, M. D., 1998. Costly capital reallocation and the effects of government spending. Carnegie-Rochester Conference Series on Public Policy, 48(1), pp. 145-194. doi: 10.1016/S0167-2231(98)00020-7

44. Ramey, V. A., 2011. Identifying government spending shocks: It's all in the timing. The Quarterly Journal of Economics, 126(1), pp. 1-50. doi: 10.1093/ qje/qjq008

45. Ravn, M. O., Schmitt-Grohe, S. and Uribe, M., 2006. Deep habits. Review of Economic Studies, 73(1), pp. 195-218. doi: 10.1111/j.1467-937X.2006.00374.x

46. Rebucci, A., 2003. On the heterogeneity bias of pooled estimators in stationary VAR specifications. International Monetary Fund Working Paper, No. 03/73.

47. Romer, C. D. and Romer, D. H., 2010. The macroeconomic effects of tax changes: Estimates based on a new measure of fiscal shocks. American Economic Review, 100(3), pp. 763-801. doi: 10.1257/aer.100.3.763

48. Romer, C. D., 2011. What do we know about the effects of fiscal policy? Separating evidence from ideology. Unpublished.

49. Rusnak, M., 2011. Why do government spending multipliers differ? A metaanalysis. Unpublished.

50. Sims, E. R., 2012. News, non-invertibility, and structural VARs. In: N. Balke [et al.], eds. DSGE models in macroeconomics: Estimation, evaluation, and new 
developments - Advances in Econometrics, Volume 28. Bingley, UK: Emerald Group Publishing Limited, pp. 81-135. doi: 10.1108/S0731-9053(2012) 0000028006

51. Smets, F. and Wouters, R., 2003. An estimated dynamic stochastic general equilibrium model of the euro area. Journal of the European Economic Association, 1(5), pp. 1123-1175. doi: 10.1162/154247603770383415

52. Smets, F. and Wouters, R., 2007. Shocks and frictions in US business cycles: A Bayesian DSGE approach. American Economic Review, 97(3), pp. 586-606. doi: 10.1257/aer.97.3.586

53. Spilimbergo, A., Symansky, S. and Schindler, M., 2009. Fiscal multipliers. International Monetary Fund Staff Position Note, No. 09/11.

54. Suyker, W., 1999. Structural budget balances: The method applied by the OECD. In: Indicators of structural budget balances. Essays presented at the Bank of Italy workshop. Perugia, Italy, 26-28 November 1999. pp. 72-96. Rome: Banca d'Italia.

55. Towbin, P. and Weber, S., 2013. Limits of floating exchange rates: The role of foreign currency debt and import structure. Journal of Development Economics, 101(C), pp. 179-194. doi: 10.1016/j.jdeveco.2012.10.007

56. Woodford, M., 2011. Simple analytics of the government expenditure multiplier. American Economic Journal: Macroeconomics, 3(1), pp. 1-35. doi: 10.1257/mac.3.1.1

57. Yang, S.-C. S., 2007. Tentative evidence of tax foresight. Economics Letters, 96(1), pp. 30-37. doi: 10.1016/j.econlet.2006.12.006 